Wiesław Walkiewicz

\title{
Znaczenie europejskiej drogi rozwoju Bałkanów i wkładu regionu w system bezpieczeństwa zbiorowego
}

Postawiona $\mathrm{w}$ tytule tezę o fundamentalnym znaczeniu opowiedzenia się przez nowe organizmy bałkańskie za integracjami euroatlantyckimi trudno jest traktować inaczej niż bezsporna, nie poddająca się w procesie weryfikacji ocenom innym. Różne są natomiast fazy realizacji tej idei przez poszczególne państwa, poziomy zdolności adaptacyjnych, wyobrażenia co do ich ról, rachunku korzyści, czy - jak w przypadku Serbii - gotowości wzniesienia się ponad urazy.

Problematyka, jaka zechcieli w tym dziele zbiorowym podzielić się inni, limituje rozważania autora do zasygnalizowania trzech segmentów tematycznych:

- wysiłków przedmiotowych państw na drodze do przekształcenia regionu o przymiotach „beczki prochu” w strefę stabilności (z pochyleniem się nad uwarunkowaniami i rozbieżnościami parcjalnymi, z odniesieniem się „komparatywnie" do zmiennych zależnych w polityce wschodniobałkańskiej Sofii i Bukaresztu);

- „systemu naczyń połączonych” w kwestii zdolności adaptacyjnych państw sukcesyjnych do środowiska, reguł i norm unijnych oraz NATO-wskich, i odwrotnie: respektowania przez układ integracyjny specyfiki i historycznych odmienności nowych podmiotów; 
- pochylenia się nad realnymi barierami i sposobami ich przezwyciężenia w procesie urzeczywistniania udziału państw bałkańskich we wspólnej europejskiej odpowiedzialności.

Słowenia, Macedonia i Chorwacja, wraz z uznaniem ich samodzielności, podobnie jak przekształcajacca się Albania ${ }^{1}$, artykułowały od początku wolę akcesu do Sojuszu Północnoatlantyckiego. Głos Lublany ${ }^{2}$ był w tym procesie tym taktyczniejszy, im pilniejsza jawiła się potrzeba zamknięcia flanki południowo-zachodniej, tj. włosko-węgierskiej, i im intensywniej czyniła jej awanse NATO-wska i unijna Bruksela. Na początku maja 2003 r. pełniaca honory gospodarza konsultacji Tirana, Skopje i Zagrzeb osiagnęły tzw. Kartę amerykańsko-adriatycka, stanowiąca - dzięki poparciu zaoceanicznego mocarstwa - promesę uzyskania członkostwa w Pakcie ${ }^{3}$.

$\mathrm{Na}$ ten gest Waszyngtonu zasadniczy wpływ miał dyskurs w sprawie sytuacji w Iraku, dzielący Europę na tzw. starą i nowa. Oprócz sojuszników, takich jak Wielka Brytania, pozyskanie nowych eksponentów (obok np. Polski, bijącej się o palmę pierwszeństwa z Turcja) stanowiło propagandowy resurs nie do przecenienia. Warunek przeprowadzenia koniecznych reform akcentowano jako prawie tak samo ważny, jak owocna i niekontestacyjna wspótpraca ze Stanami Zjednoczonymi i pozostałymi członkami Sojuszu.

${ }^{1}$ The Charter of Partnership among Albania, Croatia, Macedonia and USA, Joint Cooperation, Signing Ceremony, Tirana, May 02, 2003.

${ }^{2}$ Racje słoweńskie dobrze konceptualizuje studium V. Vegič, Interes $z a$ članstvo v zvezi NATO i prilagajanje na području nacjonalne varnosti, „Teorija in praksa" [Ljubljana] 1997, vol. 34, br. 6 .

${ }^{3} \mathrm{Na}$ ten temat zob. m.in.: M. Sošić, Hrvatska strategija europskih integracija 2000-2005, „Anali Hrvatskog politološkog društva” 2005, vol. 2, br. 1; Z. Gareljić, Što za Republiku Hrvatsku znači ulazak u NATO?, „Godišnjak Šipan 2003”, ur. L. Čehulić, Zagreb 2004. 
Kiedy na początku 1999 r. zaproszono do NATO Wegry, Czechy i Polskę, pozostali aplikujacy, nie bez pewnej frustracji, założyli tzw. Grupę Wileńskąa . Oprócz Litwy, Łotwy, Estonii i Słowacji jej sygnatariuszami były państwa bałkańskie: od Słowenii przez Albanię i Macedonię po Bułgarię i Rumunię. Gremium to powiększyła 30 maja 2001 r., przy okazji konferencji Sojuszu w Budapeszcie, mocno zabiegająca o członkostwo Chorwacja. Deklaracje sekretarza stanu USA Colina Powella składane chorwackiemu ministrowi spraw zagranicznych Tonino Piculi, pozwalały snuć nad Sawa perspektywę rychłego osiagnięcia statusu regionalnego mocarstwa, zakotwiczonego w strukturach NATO.

Przypomnijmy: w listopadzie 2002 r. podczas szczytu w Pradze zaproszenie otrzymało siedem państw: trzy niegdysiejsze republiki bałtyckie, Słowacja i trzy państwa bałkańskie: lider transformacji - Słowenia - oraz Rumunia i Bułgaria, które 29 marca 2004 r. oficjalnie „zasiliły” Sojusz. Absencję w tym gronie Chorwacji najlepiej ilustrowała wypowiedź sekretarza generalnego NATO George'a Robertsona o potrzebie gruntownych, nie tylko wojskowych, reform $w$ tym kraju. Czy rzeczywiście pozostawanie poza strukturami Paktu, gwarantującego bezpieczeństwo od północy i zachodu, oznaczało - jak uważał prezydent Chorwacji Stjepan Mesić - dla Zagrzebia polityke samobójczq? ${ }^{5}$ Może raczej znaczyło dyskomfort „zaszeregowania" do niestabilnego obszaru postjugosłowiańskiego, które to określenie dedykowano tu „rubieżom” na wschód od Lipowca i na południe od Slavonskiego Brodu.

Skróceniu dystansu do „prymusów” posłużyła wspomniana konfiguracja A-3, pozytywnie odczytywana w Waszyngtonie,

${ }^{4}$ Hrvatska u Vilnuskoj skupini [tekst agencyjny HINA], „Vjesnik” (Zagreb), $31 \mathrm{~V} 2001$.

${ }^{5}$ Mesić: Pozdrauljamo sljedeci val [artykuł redakcyjny], „Jutarnji list” (Zagreb), 22 XI 2002. 
bo starająca się przejmować doświadczenia byłych trzech republik nadbałtyckich ZSRR. Aktywności i zmiany systemowe $\mathrm{w}$ każdym $\mathrm{z}$ aplikujących krajów (ocenianym $\mathrm{z}$ osobna) były twórczym instrumentem zacieśniania relacji z Sojuszem. Do bilansu dokonań po stronie Zagrzebia wpisywało się zaproszenie na miniszczyt A3+B3 w 2006 r. na Brioni ${ }^{6}$, w roli obserwatorów, szefów dyplomacji ówczesnej Serbii oraz Bośni i Hercegowiny $(\mathrm{BiH})$. Kontynuacja tej inicjatywy w Tallinie w lutym 2006 r. uwiarygodniała szeroki projekt Planu Działań na rzecz Członkostwa (MAP) całego obszaru Bałkanów Zachodnich.

Już sama akceptacja celów, zbliżenie mimo różnic i zaszłości, stanowiły klarowny przekaz o stabilizowaniu się obszaru, stanowiącego strefę żywego zainteresowania USA (najdobitniej egzemplifikowanego wkładem do powstania państwa Kosowo). Postęp w sferze wyraźnego obniżenia poziomu zagrożeń (zmniejszenia apetytu na ryzyko) nagrodzony został w 2006 r. na szczycie w Rydze włączeniem BiH, Serbii oraz świeżo proklamowanej Czarnogóry do programu Partnerstwa dla Pokoju (PdP).

Pominięcie w zaproszeniu do NATO spełniającej wymogi, ale skazanej na przegrana w konflikcie z Atenami, Macedonii przyniosło nad Wardarem poczucie niespełnienia, na którego tle tym dobitniej jawił się sukces przyjętych w $2008 \mathrm{r}$. do Sojuszu Chorwacji i Albanii. Szczyt w Bukareszcie i „mapa drogowa" dla pozostałych organizmów postjugosłowiańskich do „pełnoprawnego" udziału w zawarowaniu bezpieczeństwa w regionie stanowiły wyznacznik pożądanego celu. Jest on stale podbudowywany udziałem przedstawicieli słoweńskich i chorwackich sił zbrojnych, policjantów i funkcjonariuszy

${ }^{6}$ Kalendarium wydarzeń zbliżających do członkostwa przynosi opracowanie M. Łakota-Micker, Republika Chorwacji na drodze do NATO, Polkowice 2011. 
państwowych w operacjach Sojuszu i misjach z mandatu Organizacji Narodów Zjednoczonych (ONZ) .

Odnośnie do przeciwległego ostańca: pod arendarzem radzieckim Bułgaria znajdowała się w strategicznie ważnym miejscu, pozwalającym na blokowanie cieśnin czarnomorskich, oraz stanowiła dogodne pozycje wyjściowe do ewentualnego konfliktu z Grecja i Turcja. Obalenie Todora Żiwkowa nie oznaczało bynajmniej końca rządów komunistycznych: podczas gdy w innych krajach dochodziło do wydarzeń jednoznacznie świadczacych o zmianach ustrojowych ${ }^{8}$, w Bułgarii proces ten obrał charakter stopniowej ewolucji 9 .

W wyniku rozwiązania Układu Warszawskiego Bułgaria znalazła się, podobnie jak inne państwa satelickie ZSRR, w obszarze swoistej próżni bezpieczeństwa. Jej dotychczasowy protektor, sukcesorska Rosja, w poszukiwaniu dla siebie nowej roli w układzie światowym musiała częściowo ograniczyć działania na arenie międzynarodowej. Wyzwanie dla sofijskiego areopagu stanowiła $\mathrm{w}$ tym kontekście potrzeba odniesienia się do dotychczas wrogich państw NATO-wskich na południu, tj. Grecji i Turcji.

Zachowanie przy władzy w Bułgarii ludzi „z pierwszej linii” miało istotny wpływ na kurs polityki zagranicznej w zakresie bezpieczeństwa, rozpoczynającego proces reformowania się państwa. W czasie rządów postkomunistów Bułgaria nie wyrażała większej woli integracji z Sojuszem, uznając

${ }^{7}$ Zob. D. Lovrić, Republika Hrvatska i NATO, [w:] R. Vukadinović, L. Čehulić, D. Lovrić, NATO u međunarodnim odnosima, Zagreb 2006.

${ }^{8}$ A. Burakowski, Butgaria - w poszukiwaniu końca komunizmu, [w:] A. Burakowski, A. Gubrynowicz, P. Ukielski, 1989 - Jesień Narodów, Warszawa 2009, s. 334 i nast.

${ }^{9} \mathrm{Na}$ ten temat zob. m.in. A. Koseski, Butgarska transformacja, [w:] Przemiany $w$ Europie Środkowo-Wschodniej. 20 lat doświadczeń, red. nauk. A. Koseski, J. Wojnicki, Pułtusk 2011, s. 200. 
za wystarczającą swoją aktywność na forum ONZ i Organizacji Bezpieczeństwa i Współpracy w Europie (OBWE). Było to zachowanie bez precedensu wśród byłych państw satelickich Związu Radzieckiego, jak i organizmów powstałych w wyniku rozpadu federacji jugosłowiańskiej. Na stanowisko Sofii znaczący wpływ miały, uwarunkowane przez historię, relacje z Rosją oraz Turcja, postrzeganie porewolucyjnego ładu społecznego tej pierwszej jako jedynego możliwego modelu rozwoju. Początek lat 90. oznaczał pod Witoszą próbę urzeczywistniania koncepcji „stabilnego rozwoju” (poprzez utrzymywanie przyjaznych stosunków z Moskwa) oraz intensyfikację kontaktów z krajami zachodnimi ${ }^{10}$. Sprawujący władzę opowiadali się za członkostwem w NATO, nie czyniąc jednak wyraźnych wysiłków w stronę jego uzyskania. Z drugiej strony starali się powielać i dostosować do swoich potrzeb pomysły rosyjskiej dyplomacji ${ }^{11}$.

Jednym z posunięć, jakie umożliwiły podniesienie poziomu zaufania w optyce Sojuszu, było nawiązanie (precyzyjniej: podniesienie szczebla) dialogu politycznego z Atenami. Szansą okazała się propozycja greckiego premiera Konstandinosa Mitsotakisa w sprawie przygranicznych stref bezpieczeństwa na Półwyspie, które byłyby wolne od broni ofensywnych. Dzięki tej inicjatywie udało się doprowadzić (13-14 listopada 1991 r.) do trójstronnego spotkania, poświęconego zagadnieniom bezpieczeństwa, na które - oprócz Grecji - zaproszona została Turcja, co dodatkowo poprawiało wizerunek

${ }^{10}$ Zob. A. Pastuszak, Polityka zagraniczna Butgarii w rejonie Morza Czarnego po zimnej wojnie, [w:] Poznać Batkany. Historia - polityka - kultura-języki. V, pod red. K. Taczyńskiej i A. Twardowskiej, Toruń 2013, s. 358-359.

${ }^{11}$ Krytyczną recenzję aktywności zagranicznej w budowie systemu bezpieczeństwa Bułgarii wystawił B. Toszew, Wynsznata politika ili mitit za Golemija brat, Sofija 2005, s. 12 i nast. 
Sofii w oczach opinii międzynarodowej. Istotnym krokiem, poczynionym $\mathrm{w}$ stronę pozytywnych tendencji $\mathrm{w}$ stosunkach z państwami regionu, było ratyfikowanie i wypełnienie umów rozbrojeniowych: 13 stycznia 1993 r. Bułgaria przystapiła do konwencji o zakazie produkcji i posiadania broni chemicznej $^{12}$.

Rozgrywający się w latach 90 . XX w., w bezpośrednim sasiedztwie, konflikt jugosłowiański okazał się trudnym doświadczeniem dla słowiańskich pobratymców na Bałkanach Wschodnich. Z powodu nałożonych na Serbię sankcji i embarga ucierpiał nie tylko bułgarski handel, ale i w warunkach spustoszonego rynku, z drugiej zaś imperatywu eksportu - cała gospodarka. Wysiłki na rzecz zmiany stanowiska USA i uzyskania zgody na transport bułgarskich produktów przez terytorium byłej federacji nie odniosły rezultatów. Mimo ważnej roli Sojuszu w regionie w pełnieniu misji, określanej jako stabilizująca, Bułgaria pozostawała krajem niezdecydowanym w kwestii wyboru strategicznego partnera w realizacji polityki obronnej. Pozycja wyczekiwania na najlepszą ofertę oraz szukanie korzyści z „gry na dwa fronty” nie stanęły jednak na przeszkodzie uczestnictwa w Partnerstwie dla Pokoju. Było to rozwiazanie dające zarówno realne gwarancje ochrony najżywotniejszych interesów narodowych ze strony Sojuszu, jak i nie nastawiało na szwank tradycyjnych relacji z Rosja ${ }^{13}$.

W założeniach PdP (swoisty surogat agregacji atlantyckiej i probierz gotowości do głębokich zmian organizmów wyszłych spod kurateli radzieckiej) miało pozwolić prowadzić politykę równowagi. Akcentowano, że Partnerstwo ma na celu zapewnienie stabilności i odpowiedniego poziomu zaufania

${ }^{12}$ V. Shalamanov, Bulgarian Defense Reform from 1990-2008 as a Change Management Process and the Role of Integrity Building, „Connections. The Quarterly Journal" 2009, vol. VIII, no. 3, s. 91.

${ }^{13}$ Ibidem, s. 93. 
na kontynencie, zwiększanie przejrzystości budżetów obronnych oraz organizowanie wspólnych ćwiczeń i współuczestnictwo stron w planowaniu obronnym poprzez cykliczne spotkania i wspólne ćwiczenia.

Pomimo zaangażowania w rzeczony program, rozstrzygnięcia na rzecz przemian, nawet jeśli reglamentowanych, jak wybory prezydenckie czy wymiany ekip rządowych, wpływały na fluktuacje paradygmatów bułgarskiej polityki bezpieczeństwa. Objęcie władzy przez ludzi ze środowiska postkomunistycznego spowodowało zmiany w podejściu do sojuszy, co wyrażała przyjęta przez parlament deklaracja, iż NATO nie respektuje dostatecznie interesów krajów członkowskich. Cezurę obrania kursu ku zachodnim strukturom wyznaczało nowe „rozdanie” w 1997 r., kiedy to wybory parlamentarne w Bułgarii wygrał Związek Sił Demokratycznych z Iwanem Kostowem na czele. Na wykluwająca się prozachodnią orientację nie bez wpływu pozostawała rosnąca przychylność środowisk opiniotwórczych, intensyfikacja kontaktów w ramach PdP oraz kryzys ekonomiczny, jaki przechodziła Federacja Rosyjska ${ }^{14}$.

Jednoznaczne opowiedzenie się za opcją atlantycką znalazło jednakowoż i oponentów, w tym części środowisk wojskowych (również wśród wyższych oficerów i samej generalicji). W lutym 1998 r. wystosowano stąd list otwarty do rządu, wyrażając sprzeciw wobec decyzji, które moga doprowadzić do ograniczenia nieskrepowanej polityki zagranicznej ${ }^{15}$. W ramach konsultacji i debat z udziałem ekspertów i frakcji politycznych udało się jednakże zatwierdzić dokumenty określające zadania państwa. W Koncepcji Bezpieczeństwa Narodowego z 1998 r. i doktrynie militarnej z 1999 r. za jedno z najważniejszych

${ }^{14}$ T. Czekalski, Butgaria, Warszawa 2010, s. 308-309.

${ }^{15}$ Zob. B. Toszew, op. cit., s. 14. 
wyzwań uznano wstapienie do NATO oraz pełna integrację ze strukturami Unii Europejskiej (UE). W 2004 r. dokonano profesjonalizacji armii poprzez ograniczenie jej liczebności (45 tys. osób w dobie pokoju i 100 tys. w czasie wojny) przy zwiększeniu nakładów na modernizację uzbrojenia.

Wydarzeniem, które rzutowało na jakość relacji między Bułgarią a społecznością transatlantycka, była interwencja NATO w Kosowie w 1999 r. Parlament pod Witoszą 4 maja 1999 r. wyraził zgodę na wykorzystywanie swojej przestrzeni powietrznej przez samoloty Sojuszu, wykonujące loty bojowe przeciw Jugosławii. Na plus społeczeństwu zapisać trzeba, że blisko 77\% obywateli sprzeciwiało się interwencji i uczestnictwu Bułgarii w operacji „Sojusznicza Siła”. Naloty, do których przylgnęło określenie „humanitarne”, doprowadziły zresztą do zniszczenia ważnych dla Bułgarów mostów na Dunaju w stolicy Serbii i w Nowym Sadzie, przez które transportowano produkty do i z czarnomorskich portów. W awansowaniu się „strategicznego zbliżenia” ważną rolę odegrało przyjęcie przez Bułgarię na jej terytorium żołnierzy USA, a także udostępnienie im jednej z największych swoich baz - w Sarafowie koło Burgas ${ }^{16}$.

Ze względu na stan wyposażenia wojska oraz znaczny koszt operacji żołnierze bułgarscy nie wzięli bezpośredniego udziału w misji irackiej, ale 380 uczestniczyło w zabezpieczaniu polskiej strefy odpowiedzialności, stacjonując w bazie koło Diwaniji do 2005 r.

Ukoronowaniem dążeń Bułgarii do zapewnienia sobie NATO-wskiego parasola było oficjalne przyjęcie w poczet państw członkowskich na szczycie w Stambule 29 marca 2004 r.

${ }^{16}$ N.K. Dotzev, The Soviet Legacy: Transforming Bulgaria's Armed Forces for Homeland Security Missions, „Connections. The Quarterly Journal" 2005, vol. IV, no. 3, s. 86. 
Obecnie jednym z głównych problemów, jakie stoją przed tym krajem $w$ sferze bezpieczeństwa, jest poziom finansowania i system rozliczania funduszy. Jak stwierdzono w raporcie z 2011 r., postawionych celów, związanych z modernizacja armii poprzez zwiększenie jej interoperacyjności z wojskami sojuszniczymi, nie udało się osiagnaçc. Jednym z problemów pozostaje bardzo wysoki poziom korupcji w strukturach odpowiedzialnych za unowocześnianie sił zbrojnych ${ }^{17}$.

Uwarunkowania owe, podobnie jak inne przypadłości, wynikające z wdruków mentalnościowych, owego (bałkańskiego) genius loci, jak przypominał Henryk Batowski, wpisały się $\mathrm{w}$ bilans otwarcia i nadal ciążą nad miejscem i rolą Bułgarii w NATO.

Dla utrzymania wywodu w dyscyplinie formalnej, to jest skoncentrowania się nie na problematyce Bałkanów Wschodnich, miast rozwijania tego wątku, korzystniej byłoby pochylić się np. nad rolą Rumunii - tak w ładzie regionalnym, jak i zadaniami, jakie wyznaczaja jej uwarunkowania bezpieczeństwa strefy Morza Czarnego. Ogląd i refleksja wiodłyby chociażby ku ważnej z punktu widzenia Sojuszu roli Bukaresztu w kształtowaniu stosunków między państwami transatlantyckimi a Mołdowa. Aktualne pozostają oczekiwania, że Rumunia - jako najbliższy sąsiad i kraj tożsamy kulturowo - ma szansę stać się nie tylko najważniejszym partnerem, ale i adwokatem interesów Kiszyniowa i Naddniestrza w NATO (podobnie jak na forum Unii Europejskiej) ${ }^{18}$.

W kwestii nurtu zasadniczego - owego „systemu naczyń połączonych" - godzi się zwrócić uwagę na specyficzne w tym rejonie uwarunkowania historyczne, polityczne i społeczne.

${ }^{17}$ White Paper on Defence and the Armed Forces of the Republic of Bulgaria, 2010, s. 16-17.

${ }^{18}$ Zob. A. Burakowski, Rumunia, „Europa Środkowo-Wschodnia”, R. XVIII: 2008 [druk 2010], s. 328-329. 
Dążność do przyjęcia na siebie zadania utrzymania niezakłócanego, jak miało to miejsce w nieodległej przeszłości, ładu pokojowego na Bałkanach jest procesem, na którego drodze, obok znalezienia się w tej samej konfiguracji (NATO, Unia Zachodnioeuropejska) nie brakuje wyzwań ciagłych ${ }^{19}$.

Zmiana środowiska międzynarodowego, przyjęcie nowych ról, determinują nie tylko politykę zagraniczna, ale uruchamiaja procesy adaptacyjne o charakterze społecznym, w tym świadomościowym, i ekonomicznym. W każdym państwie, nie tylko zatem sukcesyjnym ze sztafażem wzajemnych uprzedzeń, jeśli nie roszczeń, środowisko wewnętrzne składa się z setek elementów, zaś międzynarodowe jest równie złożone - należy mieć na uwadze skomplikowaną i zawiła, na Bałkanach bardziej może niż gdzie indziej, sieć wpływów, którym podlega polityka rządów każdego z siedmiu nowych organizmów. Polityczna racja bytu decydentów, występujących w imieniu tamtejszych etnozbiorowości, kontaminować musi obraz tak nowych stosunków międzynarodowych, jak przegląd własnego zaplecza społecznego, jego emocjonalności i „rozliczeniowości”. Celem tych procesów jest zharmonizowanie owych obrazów i, w tym przypadku stopniowe, konfrontowanie ich z rzeczywistością.

Wobec stale obecnej, podtrzymywanej przez media, hierarchii fałszywej świadomości (jak np. „dybanie” na suwerenność i terytoria sasiada) w miejsce dostosowania się do nowej sytuacji w regionie, mogą utrwalać się projekcje urojone. Nie

${ }^{19}$ Przestrzeń bezpieczeństwa w formule euroatlantyckiej wyznaczona flanką zachodnią (Słowenia, Chorwacja, Albania), wschodnią (Rumunia, Bułgaria), a także Turcja, Grecją na południu i Węgrami na północy, czyni region ten nieporównywalnie bezpieczniejszym niż w dobie dramatycznego rozpadu federacji jugosłowiańskiej, nierównoprawna pozycja innych sukcesorów (tak militarna, jak i ekonomiczna) stanowi jednak potencjalne zarzewie konfliktów społecznych. 
oznacza to, że nie „kotwiczą” na elementach prawdziwych - jak opisywane przez Curzio Malapartego okrucieństwa doby Niezależnego Państwa Chorwackiego (NDH), relacje ustaszeczetnicy-partyzanci, ekstremizm miloševiciowski czy tuđmanowski - niekiedy tworzonych sztucznie czy kreatywnie kontaminowanych. Adaptacja do warunków nie przeciw sobie, nie obok, ale $z$ soba dla bezpiecznego jutra przebiega nie tylko na poziomie wpływu rzeczywistości zagregowanej, zarządzanej z Brukseli i Waszyngtonu, ale i na poziomie wpływu odzwierciedlenia tej sytuacji w umysłach decydentów i wyborców ${ }^{20}$.

Z punktu widzenia skazanych na siebie, choć też na swoista zewnętrzną kuratelę - siła nacisku międzynarodowego na bałkańskie państwa, miejsce jego przyłożenia oraz własny potencjał nie sa możliwe do zmienienia w krótkim czasie. Zmienna zależna jest wybór strategii adaptacyjnej, a także niedostrzeganie, jak w zgasłej federacji narastaja problemy. Talcott Parsons twierdził, że każda społeczność, adaptując się do nowego środowiska, z niego powinna czerpać swoją energię i do niego się przystosowywaće ${ }^{21}$. Czy w „systemie naczyń połączonych” zachodnia hemisfera, w tym nowa Europa centralna, zechca wchodzić w taką transakcję wymiany z aktorami bałkańskimi? Czy megalomanię nad Sawą czy Dunajem da się podporządkować celom i funkcjonowaniu „szczebla wyższego”?

Odnotowujemy przykłady pozytywne: najeżona największą spośród krajów członkowskich liczbą generałów ${ }^{22}$, nie

${ }^{20}$ Artykułowane tu stany świadomości autor starał się przybliżyć w pozycji W. Walkiewicz, Jugostawia. Państwa sukcesyjne, Warszawa 2009.

${ }^{21} \mathrm{Na}$ ten temat zob. T. Parsons, The Structure of Social Action. A Stu$d y$ in Special Reference to a Group of Recent European Writers, New York 1968.

${ }^{22} \mathrm{O}$ ile u kresu bytu federacyjnego, decydujacy areopag, czyli tzw. waskie Prezydium, przyznawał racje sceptykom w kwestii potrzeby utrzymywania „na stanie” 139 generałów, jako rozdęcia kadrowego 
tylko w przeliczeniu na 100 tys. obywateli, Chorwacja nie stała się elementem destrukcyjnym w strukturach Sojuszu. Diametralnie różna ocena operacji „Burzy” z 1995 r. (widziana przez Zagrzeb jako jedna z najwspanialszych batalii wojennych w drugiej połowie XX w., a postrzegana przez Belgrad w kategoriach zorganizowanej przez chorwacką armię zbrodni na cywilach ${ }^{23}$ ) nie minuje ścieżki porozumienia i współpracy. Po stronie zmiany warto odnotować symptomy zachodzacych przewartościowań - po pierwszych frustracjach i odreagowaniach, pod amerykańską batutą bombardowań ${ }^{24}$, a także tendencji do unormowania stosunków z tymi państwami UE, które pospieszyły uznać niepodległość Kosowa ${ }^{25}$.

determinowanego roszczeniem republik oraz uhonorowania zasług, o tyle sześciokrotnie mniej liczna, suwerenna Chorwacja w szczytowym okresie awansów czynionych przez generalissimusa Franjo Tuđmana poszczycić się mogła półtysięcznymi zasobami dowódców i ... polityków, dysponujących tak wysokimi stopniami. Awansowano ich po odejściu w stan spoczynku (co oznacza tu oddelegowanie do sprawowania pieczy nad urzędami administracji centralnej, aparatem sprawiedliwości, korporacjami gospodarczymi). Republika wykazuje obecnie już tylko 362-osobowy korpus generalski, co niemniej nadal wyznacza współczynnik zdecydowanie wyższy, niż w - znanych z takich parametrów - np. Tajlandii, Malezji, czy Chile.

${ }^{23}$ Obchodzone bardzo uroczyście państwowo (zwłaszcza w czasie premierostwa Jadranki Kosor, tonowane pod Zoranem Milanoviciem) „Dni dumy i sławy” oraz fetowane hucznie kombatancko kolejne rocznice „Burzy” stanowią dla Chorwatów apoteozę wojennej chwały. W 2008 r. prezydent S. Mesić zdobył się na oficjalne przeproszenie Serbów za przebieg tej akcji.

${ }^{24} \mathrm{~W}$ rozpoczętych 24 marca 1999 r. nalotach, samoloty NATO zniszczyły większość baz jugosłowiańskich, fabryk broni, co najmniej trzy maszyny „wroga” i według różnych wersji od kilkunastu do 90 czołgów.

${ }^{25}$ Spośród ponad 100 państw, jakie uznały Kosowo, po proklamacji niepodległościowej 17 lutego 2008 r., za nowy samodzielny podmiot stosunków międzynarodowych, znajdują się 23 przynależące do UE; w Serbii długo utyskiwano na fakt, iż pierwsza ze słowiańskich stolic, która powitała w ten sposób nowy prisztinski byt, była Warszawa. 
Prognozy w kwestii tych i podobnych im pytań obciążone są sporym ryzykiem błędu. Dyscyplinując powyższe dywagacje powracamy $\mathrm{w}$ koleiny tematyki bezpieczeństwa dla Europy. Modelowi zbiorowego bezpieczeństwa Starego Kontynentu, funkcjom OBWE, działalności prewencyjnej, kontroli zbrojeń (CFT Treaty), misjom obserwacyjnym, Wspólnej Polityce Zagranicznej i Bezpieczeństwa itd. - nie dane było na Bałkanach odnieść sukcesu. Podobnie zresztą jak poprzez mandat spóźniony i źle zdefiniowany fiasko przyniosły przedsięwzięcia Rady Bezpieczeństwa ONZ - wojskowe misje stabilizacyjne, złożone z kontyngentów narodowych.

Wśród potencjalnych perturbacji w osiagnięciu ambitnego celu budowy strefy bezpieczeństwa na Bałkanach i wdrożenia skutecznych narzędzi jej trwałości dostrzegać trzeba takie czynniki, jak: nasilone (zwłaszcza w Chorwacji, Serbii, ale także BiH, Macedonii czy Czarnogórze) eksponowanie „polityki historycznej”, nacjonalizm (w niektórych przypadkach z przedrostkiem „hiper”), słabości edukacji obywatelskiej, rozwinięte partyjniactwo, oddziaływujace nadal mity i stereotypy społeczne ${ }^{26}$.

Należy wierzyć, że w miarę „tężenia” procesu integracyjnego powstaną warunki do zawężania się pola oddziaływania populizmów, nadrealnych oczekiwań, roszczeń, rewizjonizmów, różnego rodzaju „rachunków krzywd”, niezależnie od tego, na ile prawdziwych. W realiach bałkańskich nie sposób przewidzieć poziom zachowania pryncypiów integracyjnych w ramach agendy politycznej tamtejszych rządów, podobnie jak trwałość trendów (zdolności koncyliacyjnych)

${ }^{26} \mathrm{~W}$ oglądzie przedmiotowej problematyki przydatne sa opracowania dotyczące wszystkich, z wyłączeniem Słowenii, organizmów sukcesyjnych, zawarte w pracy „Rocznik Instytutu Europy Środkowo-Wschodniej” 2011, R. 9, z. 2, Konflikty narodowe i europejskie aspiracje państw batkańskich, red. M. Filipowicz. 
na poziomie międzynarodowym. W dotychczasowych poczynaniach podmiotów bałkańskich zbyt często przejawia się prymat taktyki nad strategia długookresowa. W wielu przypadkach aktywność dyplomacji pokojowej jawiła się kontrproduktywnie, a fobie oraz mity (partnerstwo z USA i Niemcami z jednej, z Rosją z drugiej strony) zakłócały racjonalność polityki.

Zgasła federacja zawarowywać miała relatywne bezpieczeństwo regionalne w dobie zagrożeń o charakterze globalnym. Kres bipolarnej konfrontacji Wschód-Zachód zbiegł się $\mathrm{w}$ czasie z totalnym załamaniem się pokojowego ładu na Bałkanach Zachodnich. Wspólne państwo nie uratowało Słowenii, Chorwacji, Bośni i Hercegowiny, Macedonii od krwawych konfliktów, a Serbii od secesji Kosowa. Można, oczywiście, za gen. Antonem Tusem ripostować, że członkostwo w bloku wschodnim nie zaoszczędziło narodowego dramatu Węgrom, a 12 lat później Czechom i Słowakom. Członkostwo w NATO nie spacyfikowało konfliktu Grecji i Turcji na Cyprze ${ }^{27}$. Architektura bezpieczeństwa Europy, zasadzająca się na równowadze strachu, nie wytrzymała próby czasu.

Narody Zjednoczone nie maja swoich sił zbrojnych (w sensie stanu opartego na narodowych kontyngentach, zintegrowanej struktury, jednego dowództwa), a konsensus decyzyjny w Radzie Bezpieczeństwa czyni ich wysiłki częstokroć nieefektywnymi. Unia, w odróżnieniu od jej poprzedniczki - Europejskiej Wspólnoty Gospodarczej (EWG) - obejmuje swymi działaniami wspólną politykę zagraniczną i obronna. Dla ich wsparcia Unia Zachodnioeuropejska dysponuje Eurokorpusem z 50 tys. żołnierzy w stanie stałej gotowości.

${ }^{27}$ A. Tus, Sigurnosna politika Europe: stanje, problemi, rješenja i sigurnost Republike Hrvatske, „Zbornik Diplomatske škole” [Zagreb] 1997, god. 2, br. 1, s. 207-217. 
Nie trzeba przekonywać, że są to resursy tyle znaczne, co całkowicie niewystarczajace.

NATO pozostaje fundamentalnym oparciem dla nowego ładu pokojowego w Europie, umożliwiając bezpieczeństwo i stabilność przestrzeni euroatlantyckiej, zawarowując tym samym bezpieczeństwo półkuli północnej (w tej mierze i organizmom sukcesyjnym na Półwyspie). Pytanie o alternatywę ma charakter akademicki. Neutralność jako odpowiedź w realiach chorwackich, słoweńskich, macedońskich, czarnogórskich czy serbskich oznaczałaby brak parasola ochronnego, niski poziom bezpieczeństwa - generujące wysiłek zbrojeniowy, mobilizację i stała gotowość sił zbrojnych ${ }^{28}$. Spełnianie tych wymogów równałoby się z rezygnacją z priorytetów rozwoju gospodarczego. Nowe „niezaangażowanie” w tym przypadku przekładałoby się na utratę możliwych sprzymierzeńców, brak wsparcia technicznego, szkoleniowego, planistycznego - na izolację. By narody Europy (w tym południowo-wschodniej, leczącej rany) czuć się mogły nie zagrożone, jako imperatyw jawi się potrzeba wspólnego bezpieczeństwa (wojskowego, politycznego, ekonomicznego, socjalnego itd.). Jest to wyzwanie ambitne ${ }^{29}$, wymagające determinacji, wyrzeczeń

${ }^{28}$ Interesujaccej lektury dostarczają studia: A. Gucka, Czy Unia Europejska ponosi winę za kryzys polityczny w Bośni i Hercegowinie?, [w:] Konflikty militarne i niemilitarne na Batkanach $w$ XX $i$ XXI wieku $w$ perspektywie polemologicznej, pod red. D. Gibas-Krzak i A. Krzaka, SzczecinWarszawa 2013; M. Awadziun, NATO-Jugostawia. Klasyczny wymiar konfliktu zbrojnego czy wojna trzeciej generacji?, [w:] ibidem.

${ }^{29}$ Czarnogóra, wraz z Serbią oraz Bośnią i Hercegowina, zaproszona została do udziału w programie Partnerstwo dla Pokoju podczas szczytu Sojuszu w Rydze w listopadzie 2006 r. Oficjalne przystapienie odnotowuje się na połowę grudnia 2006 r., a 25 sierpnia 2007 r. Podgorica podpisała z NATO porozumienie dotyczace bezpieczeństwa, zob. np. A. Skieterska, Czarnogóra, „Europa Środkowo-Wschodnia”, R. XVII: 2007 [druk 2009], s. 118. 
i środków, przy których inauguracyjny wkład Podgoricy w postaci redukcji nadwyżek „małej” broni, ale też przetopienia 61 z 62 „flagowych” T-55, nagrodzone $6 \mathrm{mln}$ euro i 2 mln dolarów ${ }^{30}$, jest miara żadna.

Pojęcie bezpieczeństwa wymaga obecnie zdecydowanie innej definicji niż stosowane do niedawna tradycyjne pojmowanie jego istoty. Dynamika i powiązalność zdarzeń, rzutujących na sytuację społeczną zglobalizowanego świata, zdają się determinować potrzebę odejścia od klasycznych ujęć postrzegania bezpieczeństwa przez pryzmat zagrożeń, ich identyfikacji i poziomu natężenia ${ }^{31}$. Badacze, koncentrujacy się na analizowaniu poziomu zagrożeń w regionach, gdzie wielokrotnie wiodły one ku eskalacjom i rozstrzyganiu z udziałem tysięcy ofiar, co poniekąd jest też znakiem firmowym, przedkładanej tu przez Centrum Naukowo-Badawcze Uniwersytetu Łódzkiego „Bałkany na przełomie XX/XXI w.” publikacji - winni utożsamiać bezpieczeństwo nie tylko z siłą militarna, która (nie) była, może być (bądź też nie) w stanie stawić czoła wyzwaniom.

Wartki nurt najnowszych, tradycyjnie krwawych, dziejów Słowiańszczyzny Południowej uświadamia potrzebę innego, szerszego oglądu uwarunkowań i resursów w kwestii bezpieczeństwa - nie ograniczającego się wyłącznie do obszaru potencjału zbrojnego, woli utrzymania pokoju bądź dążeniu

${ }^{30}$ Czarnogóra rozpoczęła wiosną 2007 r., wsparty przez ONZ, program rozwoju oraz promowany przez OBWE program dotyczacy zmniejszenia arsenału broni z ponad 9 tys. ton do około 2 tys. ton (mający trwać do 2009 r.), co - według oceny ambasadora USA w tym kraju Rodericka Moore'a, zmniejsza ryzyko wejścia $w$ jej posiadanie przez organizacje terrorystyczne, zob. U.S. funds montenegrin arms reduction, RFE/RL Newsline, http:// www.rferl.org/content/Article/1144007.html.

${ }^{31}$ Zob. m.in. R. Zięba, Wprowadzenie, [w:] Bezpieczeństwo międzynarodowe po zimnej wojnie, red. nauk. R. Zięba, Warszawa 2008, s. 15-16. 
(i realizacji) celów na drodze rozstrzygnięć siłowych. Jak słusznie zauważa Anna Antczak-Barzan, owa wymuszona zmiana optyki niesie z sobą również pierwiastek pozytywny - każe postrzegać bezpieczeństwo jako warunek niezbędny już nie tylko do przetrwania, ale także rozwoju ${ }^{32}$ (w przedmiotowej materii bytów państwowych całkowicie nowych, jak Słowenia, Macedonia, reaktywowanych z efemerycznych uwikłań, jak Chorwacja, „fantomowych”33, jak Bośnia i Hercegowina czy Kosowo, wreszcie przywróconych na pozycje historycznie zajmowane - jak Serbia czy Czarnogóra).

Nieprzydawanie właściwej miary analizom przedmiotowego charakteru bezpieczeństwa, a zatem jego aspektowi politycznemu, społeczno-ekonomicznemu, rozregulowanym mechanizmom moralnym, konfliktom etnicznym na równi z systemami sojuszów, poziomem uzbrojenia, stanami armii itd., czyni funkcje prognostyczne i analizy bieżące $\mathrm{w}$ dużym stopniu ułomnymi. Jak mało gdzie, elementem istotnym w próbie przerzucania mostów nad starymi i nowymi mogiłami jest zdolność do refleksji, samooceny i gotowość do wzięcia na siebie współodpowiedzialności - tak za zdarzenia niedawne, jak i za rzeczywistość, która nadejdzie. Władza pieniądza, doprowadzona do fetyszu zaradność życiowa, od Albanii przez Bośnię, Bułgarię, Chorwację, Czarnogórę (by pozostać przy poprawności alfabetycznej) po Kosowo i Serbię, stłumiła

${ }^{32}$ A. Antczak-Barzan, Rangi wyzwań dla bezpieczeństwa Polski w XXI wieku, [w:] Wybrane problemy bezpieczeństwa wewnętrznego państw, pod red. A. Misiuka, Warszawa 2014 (seria: „Studia Politologiczne” 2014, vol. 34), s. 226.

${ }^{33}$ Określenie Bośni i Hercegowiny jako „państwo-fantom”, wprowadzone do obiegu przez badawczy z Europy Środkowej i Wschodniej (m.in. z Czech i Federacji Rosyjskiej) w pierwszej dekadzie nowego Millenium, oddajace istotę rzeczy, wygenerowało adekwatne do tamtejszej sytuacji instrumentarium analityczne. 
wartości obywatelskie. Ostentacyjne obnoszenie się z bogactwem wyniesionym $\mathrm{z}$ wojennego biznesu (wspaniałe, historyczne zamki, rezydencje, jakie trudno spotkać na Lazurowym Wybrzeżu, jet-set'y, kolekcje wybitnych dzieł sztuki, zagraniczne posiadłości), nie moga nie budzić frustracji tych, którym nie dane było w profitach uczestniczyć. Gniewu, częstokroć żalu tych, którzy, powodowani wolą wsparcia walki „za sprawę", poświęcili jej dorobek życia (a taką postawę wykazywało tysiące emigrantów), a dla których brakło miejsca przy biesiadnym stole.

Co powiedzieć wdowom, osieroconym dzieciom, czy osamotnionym przez przedwczesną śmierć synów w wojennym chaosie rodzicom? Atrapowy charakter dialogu społecznego jest dowodem braku zapotrzebowania na demokrację. Badaczom przychodzi skonstatować, że nauka zaangażowała się tam w proces tłumaczenia rzeczywistości politycznej, dla której autorytaryzm okazał się droga optymalna, a przynajmniej skuteczną.

Godzi się przypomnieć, że bezpieczeństwo nie jest wyłącznie stanem, ale przede wszystkim dynamicznym procesem, na który wywierają wpływ różnorodne implikacje i determinanty. Dla wyboru właściwej optyki w postrzeganiu i ocenie poziomu zagrożeń (stawianie hipotezy o ich niewystępowaniu w odniesieniu do regionu byłoby co najmniej nieroztropne) nie sposób uniknąc pytań o wyzwania i czynniki, jakie mają (lub mogą mieć) ważki wpływ na kwestie związane z ustrzeżeniem się południowosłowiańskich sąsiadów od konfliktów na miarę chociażby tych z lat 1941-1945 czy z lat 90 . XX w.

Jak mało gdzie (nawet $\mathrm{w}$ państwach poszerzonej zachodniej hemisfery, w tym graniczacych, jak Słowacja czy Węgry, z Ukraina poddawana próbie przez Rosję) wiele zależeć będzie od uwarunkowań zewnętrznych, na które słabe organizmy (Macedonia, BiH jako „całość”, Federacja Bośni 
i Hercegowiny, w antynomii Republika Serbska, Kosowo czy Czarnogóra) moga mieć wpływ znikomy. Wyzwanie wynikające z określonych trendów (kierunków, tendencji), jakie są zauważalne podczas śledzenia różnego rodzaju czynników wpływających na zachowanie podmiotów na arenie międzynarodowej, nie posiada ani „pierwiastka” dodatniego, ani ujemnego. To determinanty wewnętrzne i zewnętrzne decyduja, czy wyzwanie przerodzi się w zagrożenie, czy też w szansę ${ }^{34}$. Nie inaczej traktować trzeba potencjalne otwarcie problemów, które, oby nie wyszły z niegdyś stabilizującej bałkański układ sił, dziś sfrustrowanej, stojącej na rozdrożu Serbii. Niełatwo w tym miejscu znaleźć odpowiedź na pytania stawiane chociażby przez publicystkę belgradzkich „Vesti” Jelenę Petković: Czy zmęczeni codziennościa (dodajmy: strukturalnym niedostatkiem) jej rodacy, którzy zajęli się wszystkimi, na których ciąży odium przestępstw okresu wojny domowej, bezsilni i pamiętajacy, że NATO zrzucało im na głowę bomby ${ }^{35}$, wzbogacone odrobiną uranu ${ }^{36}$ - nie zechca procesu przezwyciężania niechęci i rachunku krzywd zaniechać?

${ }^{34} \mathrm{Na}$ ten temat szerzej: J. Wojnarowski, Wspótczesne wyzwania $i$ zagrożenia dla systemu bezpieczeństwa państwa, [w:] Narodowy system pogotowia kryzysowego, red. Z. Piątek, Warszawa 2007, s. 11; A. Majchrzak, Typologia zagrożen, [w:] Europa - bezpieczny kontynent? Potencjalne źródta zagrożeń bezpieczeństwa europejskiego, red. A. Antczak, Warszawa 2011, s. $16-17$.

${ }^{35} \mathrm{Na}$ kosztującą ponad 8 mld dolarów interwencję, argumentowaną zapewnieniem stabilizacji w regionie, złożyło się 23 tys. nalotów dokonanych w ciagu 78 dni. Samoloty NATO zniszczyły na terenie Serbii większość baz armii jugosłowiańskiej, fabryk zbrojeniowych. Oprócz węzłów kolejowych, zakładów przemysłowych trafiano w cywilne szpitale, przedszkola, szkoły, obozy uchodźców, pociagi pasażerskie, autobusy z uciekinierami, a także, omyłkowo, 7 maja 1999 r., w ambasadę Chin.

${ }^{36}$ „Pokojowe naloty” na Serbię spotkały się z protestami wielu środowisk, manifestacyjnymi pochodami, m.in. w Paryżu, Sztokholmie i Budapeszcie. 
Czyż deklaracja Skupsztiny, ogłaszająca neutralność państwa w końcu 2007 r. (równie ostentacyjna, co nie skutkująca notyfikowaniem przez któregokolwiek z bliższych i dalszych sassiadów), nie była wyrazem narodowej frustracji wobec ewidentnej stronniczości wspólnoty międzynarodowej, braku woli Sojuszu do rzeczywistych postępów w zbliżeniu do doń organizmu, który, opierając się przez dziesięcio- (jeśli nie stu-) lecia obcej dominacji stanowił na Bałkanach Piemont Słowiańszczyzny? Czy świat chce pamiętać, że ta społeczność, boleśnie przegrana, była w obu wojnach powszechnych ważnym ogniwem pokojowej koalicji, a po zakończeniu drugiej miała odwagę przeciwstawić się Związkowi Radzieckiemu, stawić czoła wyizolowaniu przez jego satelitów? To prawda, że w latach 90. XX w. Serbowie nie tylko z powodu upokorzeń w Kosowie ulegli ułudzie nacjonalizmu, później jednak własnymi rękoma obalili Slobodana Miloševicia, pojmali Radovana Karadžicia, Ratko Mladicia, wysłali bądź zmusili do stawienia się przed Międzynarodowym Trybunałem Karnym dla byłej Jugosławii (ICTY) Milana Milutinovicia, Biljany Plavšić, Momčilo Perišicia, Vladimira Lazarevicia, Sretana Lukicia, Vojislava Šešelja, Veselina Šljivančanina ${ }^{37}$, długie zagony wysokich ranga dygnitarzy i wojskowych ${ }^{38}$, stawiając na wizję wspólnej, bezpiecznej Europy.

Z pewną konsternacja przyjęto radiową wypowiedź szefa polskiej dyplomacji, Bronisława Geremka, wyrażającego zadowolenie ze zdecydowanej akcji NATO. W kręgach dyplomatycznych porównywano ją do enuncjacji czechosłowackiego ministra spraw zagranicznych, Bohuslava Chnioupka, który poproszony 14 grudnia 1981 r. na lotnisku Köln/Bonn o komentarz do sytuacji w Polsce, oznajmił: Jetzt wird dort der Ordnung!.

${ }^{37}$ Więcej zob. W. Walkiewicz, op. cit., s. 466.

${ }^{38}$ Nie bez znaczenia dla aury zbliżenia, chociażby na linii Belgrad-Zagrzeb, pozostaje klimat bohaterszczyzny, kultu i najwyższych honorów, kierowany przez kręgi rządowe, właściwie odczytujące nastroje społeczne nad Sawą wobec dowódców jednostek regularnych i sił paramilitarnych, w tym 
Kwestię orientacji zewnątrzpolitycznej Belgradu postrzegać należy jako rozwojowa, zależną od wielu zmiennych. O ile deklaracja Serbskiej Partii Socjalistycznej na temat potrzeby ogłoszenia przez państwo jego neutralności (z 27 października 2007 r.) zdawała się wpisywać $\mathrm{w}$ ostentacje zwiąane $\mathrm{z}$ odejściem Vojislava Koštunicy, to reakcja uczestników tamtejszej sceny politycznej na apel o sojuszników dla nowego statusu międzynarodowego nie mogła nie zaskakiwać. Swoiste votum nieufności względem „indyferentnego" Sojuszu wyrażała przyjęta w dwa miesiące później (26 grudnia 2007 r.) rezolucja Zgromadzenia Narodowego Republiki Serbii o ochronie suwerenności, integralności terytorialnej i ładu konstytucyjnego, solemnizująca inicjatywę najsilniejszego ugrupowania parlamentarnego $0^{39}$.

Na usztywnienie stanowiska Belgradu wpłynęły m.in. wydarzenia z marca 2004 r., podczas których spalenie wieluset serbskich domów, kilkudziesięciu klasztorów i cerkwi w Kosowie przez bojówki kosowarskie nie napotkało na sprzeciw tzw. opinii międzynarodowej, a ogłoszona rok później Narodowa Strategia na rzecz Integracji zdała się umknąć uwadze decydentów w Brukseli ${ }^{40}$. Frustracji dopełniało nieawansowanie się „nowego otwarcia" w ramach Rady Współpracy Północnoatlantyckiej (The North Atlantic Cooperation Council, NACC), w praktyce - podniesienia współpracy wojskowej NATO z partnerami

generałów Ante Gotoviny, Mladena Markača, Ante Rosso, Tihomira Blaškicia i wielu innych, którym „udało się” szczęśliwie odeprzeć zarzuty ICTY dotyczące przestępstw wojennych, w tym zbrodni przeciw ludzkości.

${ }^{39} \mathrm{http}$ ://www.dssns.rs/wp-content/uploads/deklaracija-o-vojnoj-neutralnosti-srbije.pdf; zob. też m.in. J. Litavski, The controversies of Military Neutrality of Serbia, The New Century, August 2012, http://ceas-serbia.org/ root/prilozi/05-eng.pdf.

${ }^{40}$ Czołowe ugrupowania polityczne postrzegały to $\mathrm{w}$ kategoriach niezafunkcjonowania w odniesieniu do Serbii zmodyfikowanych na szczycie w Salonikach (czerwiec 2003 r.) zasad współpracy w obszarach należących do Wspólnej Polityki Zagranicznej i Bezpieczeństwa. 
z grona państw należacych do OBWE (zwiększenia interoperacyjności, współdziałania sił zbrojnych itd.). Proeuropejska i proatlantycka orientacja Serbii, potwierdzona w wyborach majowych 2008 r. (zwycięstwo koalicji prezydenta Borisa Tadicia), zdawała się pod rządami Mirko Cvetkovicia dawać gwarancje przyspieszenia procesu akcesyjnego do obu agregacji ${ }^{41}$.

O ile wpisywanie - po spektakularnej uchwale Skupsztiny w kwestii neutralności - Federacji Rosyjskiej jako strategicznego partnera w ogłaszane odtąd doktryny i programy polityki bezpieczeństwa nie może (w bałkańskich realiach) nie budzić obaw, to czynniki tamtejsze dalekie sa od kursu faktycznej samoizolacji ${ }^{42}$. Ochłodzenie relacji ze Stanami Zjednoczonymi (głównym decydentem w sprawach rozszerzenia Sojuszu, po urzeczywistnieniu dążeń Waszyngtonu odnośnie Kosowa) nie zmienia optyki co do aspiracji przynależenia do zachodniej hemisfery. Wiele wskazuje na to, że Belgrad satysfakcjonowałaby najbardziej swoista, racjonalna i pragmatyczna dwutorowość: utrzymywanie tradycyjnie dobrych, a nawet bardzo dobrych, relacji z Rosja, oparcie się o jej resursy sektora energetycznego, przemysłu maszynowego itd., z drugiej jednak strony uzyskanie w systemie obronnym statusu identycznego, jak secesyjna Słowenia, a zwłaszcza Chorwacja ${ }^{43}$.

${ }^{41}$ Egzemplifikacją woli tak rządzących, jak i społeczeństwa było aresztowanie 20 lipca 2008 r. R. Karadžicia, jednego z trzech ostatnich przestępców wojennych (obok R. Mladicia i Gorana Hadžicia), ściganych przez ICTY.

${ }^{42}$ Dowodem jest wdrażana zasada dobrosasiedzkich relacji ościennych: rekoncyliacja z Chorwacją i BiH, przyjęcie przez parlament w Belgradzie w marcu 2010 r. deklaracji potępiającej zbrodnię srebrenicka, hołd ofiarom złożony w podvukovarskiej osadzie Ovčara, unormowanie stosunków z Czarnogórą i wysiłki na rzecz ich polepszenia z Albania, zaangażowanie we współpracę regionalna.

${ }^{43}$ M. Kovačević, Prioriteti spoljne politike ostaju nepromenjeni u 2009, „Politika”, 10 I 2009, s. 5. Dwa dni później stołeczna BETA zamieściła tekst stanowiący wykładnię: Tadić: za Srbiju važni odnosi sa EU, Rusijom i SAD. 
Znajacy realia bałkańskie an gros, bez wyodrębniania zachodniej części Półwyspu, wiedza, że wiele z ambitnych tutejszych wyzwań niesie ze soba co najmniej tyle samo zagrożeń (niekiedy tych najpoważniejszych) niż szans. Jeśli obecny kurs premiowania (nawet bez przedrostka „hiper”) Zagrzebia czy Prisztiny, przy jednoczesnym deprecjonowaniu prosojuszowych dążeń gremiów, np. w Skopje czy Podgoricy, zostanie utrzymany, istnieje duże prawdopodobieństwo ich wystapienia w niezbyt odległej przyszłości. Owe nadzieje i ryzyka przyjmować należy w tym kontekście jako specyficzne dla obszaru, nie dające się zawęzić do spraw wewnętrznych bytów dziś odrębnych, acz wyrosłych z formacji wspólnej, z wszystkimi faktu tego konsekwencjami i uwikłaniami. Obok trendów globalnych, jak np. postęp technologiczny, multilateralizm, potrzeba kontroli nad cyberprzestrzenia, stosowanie środków miękkich - detonatorem $\mathrm{w}$ tym regionie stać się mogą takie elementy, jak: irredenta albańska, animozje macedońsko-bułgarskie, nieco tylko przygaszone pretensje coraz liczniejszych Kosowarów nad Wardarem ${ }^{44}$, nieuregulowane problemy własnościowe (m.in. Serbów w Chorwacji).

Członkostwo flankowych państw regionu w NATO, permanentny monitoring, czyniony przez przedstawicieli Sojuszu, „oćwiczenie się” np. z logistyką lotnisk, zdaja się gwarantować niedopuszczenie do powtórzenia się sytuacji, jaka miała miejsce na Bałkanach Zachodnich w latach 1991-1995. Nie oznacza to, że wyeliminowane zostały wszystkie elementy, jakie wówczas determinowały eskalację, przede wszystkim dążenia irredentystyczne wobec terytorium BiH - tak Serbii, jak i restytuującej się Chorwacji,

${ }^{44}$ Zob. więcej: I. Stawowy-Kawka, Kosowo - problemy narodowe, „Prace Komisji Środkowoeuropejskiej PAU” 2002, t. X; J. Stańczyk, NATO w Kosowie: kontrowersje i implikacje, „Kwartalnik Bellona” 2009, R. 3, nr 3. 
dyktowane pozostawaniem tam znaczącej części ich korpusu narodowego (37,6\% ogółu społeczności republiki dążących do zjednoczenia z tą pierwsza, $20,6 \%{ }^{45}$ - identyfikujących się z tą druga). Stały się one zarzewiem konfliktów, najczęściej oznaczajaccych (razem lub z osobna) bezpardonowe, krwawe walki o nabytki terytorialne, tj. inkorporowanie ziem zamieszkałych przez „własny etnos”.

Czy jednak rzeczywiście wojna była, jak dowodził w wywiadzie dla sarajewskich mediów w marcu 2012 r. pierwszy prezydent Słowenii, Milan Kučan, rezultatem nieurzeczywistnionej umowy między Miloševiciem i Tuđmanem ${ }^{46}$ o podziale tej prowincji? Spotkanie obu tych polityków, do czego dążył ten drugi, odbyło się 25 marca 1991 r. w Karđorđevie, lub jak, unikając szczegółów, informowała rządowa agencja prasowa $-w$ granicznym obszarze republik ${ }^{47}$. Według świadka wydarzenia (późniejszego premiera Chorwacji - Hrvoje Šarinicia) ${ }^{48}$, adwersarze pochylać się mieli nad mapq Bośni, $z$ zaznaczonq na niej liniq aspiracji. W innych opiniach wymiana stanowisk koncentrowała się głównie na kwestii relacji Belgradu ze Słowenia, wiodąc, siłą rzeczy, ku stosunkowi tego pierwszego względem Zagrzebia $w$ perspektywie rychtej

${ }^{45}$ Według innych danych $17,8 \%$.

${ }^{46} \mathrm{http}: / /$ www.tportal.hr/vjesti/svijet/186613/Rat-u-BiH-temeljen-na-ugovoru-Milosevic-Tudman.html.

${ }^{47}$ Kronologija rata. Agresija na Hrvatsku $i$ Bosnu $i$ Hercegovinu (s naglaskom na stradanja Hrvata u BiH) (1989-1998), Zagreb 1998, s. 44 (za agencją: Vjesnik: „Milošević $i$ Tuđman sastali se na granici”, Zagreb, 26 ožujka 1991).

${ }^{48} \mathrm{~W}$ deprecjonowaniu wiarygodności relacji punktem wsparcia jest rozejście się dróg ongiś dwóch pierwszych mężów w państwie po tragicznej, „nie do końca wyjaśnionej”, śmierci w 1998 r. starszego syna Šarinicia, przez kilka lat pilotującego prezydenckiego jet-set’a, w tydzień później - ciężkim wypadku drogowym młodszego. Zdarzenia te łączy się z zapowiedzią ujawnienia przez ojca kulis jednej z afer gospodarczych. 
dymisji [Ante] Markovicia ${ }^{49}$. Podczas gdy przewidziany do federalnego odstrzatu przewodniczący Związkowej Rady Wykonawczej (SIV) gościł w Londynie, otrzymując poparcie Johna Majora dla wysiłków mających utrzymać jugostowiańska jedność, chorwacki prezydent, 15 kwietnia $1991 \mathrm{r}$. w barańskim „leśnym pałacu” Tikveš, kontynuował dialog z serbskim interlokutorem, oficjalnie uwieńczony obopólnym przystaniem na rozmowy grup eksperckich oraz delegacji Saboru $i$ Skupsztiny ${ }^{50}$. Nie wdając się w dyskurs na temat suponowanych innych roztrzasanych tam zagadnien, godzi się zacytować jedynie sarajewski tygodnik, podsumowujący kolejne konsultacje „na szczycie”, tym razem w Splicie, z doproszeniem przywódcy BiH Aliji Izetbegovicia (12 czerwca 1991 r.), jako pakt trzech o podziale republiki ${ }^{51}$.

Narzucone cztery i pół roku później porozumienie z Dayton, uświetnione światową celebrą podpisania w Paryżu układu pokojowego, spowodowało ucichnięcie wytoczonych przeciwko sobie dział. Nie stanowiło jednak o przesileniu wrogości, wzajemnych pretensji czy sasiedzkiej zdrady (w tym przypadku okrojenie obszaru bośniackiego, będące dla Muzułmanów dowodem narodowego poniżenia, dla Serbów, którym przyszło zapłacić wysoką cenę za wizje „wszystkich rodaków pod jednym dachem" - tematem tabu, dla kręgów objaśniajaco-propagandowych chorwackich - mitem założycielskim, mistyfikacja jakiej imają się przeciwnicy, by obniżyć rangę strategicznego geniuszu Tuđmana ${ }^{52}$ ).

${ }^{49}$ M. Tuđman, Programiranje istine, rasprava o preraspodjelima društvenih zaliha znanja, Zagreb 2012, s. 99.

${ }^{50}$ „Borba” (Beograd), 16 IV 1991, s. 1.

${ }^{51}$ Tuđman, Milošević, Izetbegović. Trojni pakt za podjelu Bosne i Hercegovine, „Bosanski pogledi” (Sarajevo), 13 VI 1991.

52 Zob. I. Lučić, Uzroci rata. Bosna i Hercegovina od 1980. do 1992. godine, Zagreb 2013, s. 378-473. 
Niewykluczone, że swoistemu katharsis, próbie przymknięcia ciagle otwartej księgi ciężkich przewinień, popełnianych podłości, wysiedleń, zbrodni (w tym klasyfikowanych przez świat jako zbrodnie przeciw ludzkości) posłużyłoby wycofanie się, chociażby z szacunku do ofiar, jakich nie brakowało po żadnej ze stron, z bezpodstawnych oskarżen, jak np. przypisania wojskom gen. R. Mladicia ataku z użyciem granatników 28 sierpnia 1995 r. na targowisko Markale. Śmierć 68 osób i rany blisko 200 kolejnych negliżowały trwałość bośniackich rozejmów i - co ważniejsze - jak deklarowano w Waszyngtonie i Londynie, wyczerpywała też cierpliwość Zachodu $^{53}$. Przez to już następnego dnia kierownictwo Sojuszu

${ }^{53}$ Po początkowej fali oburzenia, ustalenia specjalnej komisji sugerowały, iż to nie Serbowie byli sprawcami ataku (drugiego w tym miejscu na przestrzeni półtora roku - pierwszy miał miejsce 5 lutego 1994 r.), wbrew domaganiu się przez Aliję Izetbegovicia uznania, bez postronnego śledztwa, ich „winy” za bezsporną i wymagająca najsurowszej kary. Materiał wybuchowy został najprawdopodobniej podłożony przez „kogoś z miejscowych" pod jeden ze straganów. O odpowiedzialności bośniackiej, tj. muzułmańskiej, wspominają m.in. gen. Louis MacKenzie, były premier Francji Édouard Balladur, więcej zob. P.M. Gallois, Le sang du patrole - Bosnie, Lausanne 1996, s. 259-260. Dwa lata po zamachu lord Dawid Owen w swoich wspomnieniach (Balkan Odyssey) wyjawił, że wysłannicy ONZ nie potwierdzili „serbskiego śladu” na Markalach. Nad East River ograniczono do minimum dostęp do ustaleń, celem zablokowania ewentualnego przecieku do mediów: Mieliśmy bardzo poważny problem...Gdyby nagle rozprysto się powszechne przekonanie, że za bombę na bazarze nie odpowiadaja Serbowie [...]. To, czego nam byto potrzeba, to niewielka manipulacja wiadomościami... Nie godzący się z tymi racjami, jak np. rosyjski płk Andrej Demurenko, dowodzący, że prawa balistyki zaprzeczaja, by pocisk wystrzelony $z$ serbskich pozycji mógt trafić $w$ stragan na Markalach, zmuszeni byli pod naciskiem „góry” opuścić Bośnię. Niewątpliwie miał rację jeden ze świadków tragedii, w rozmowie z polskim dziennikarzem, mówiąc: To sq Batkany, za pieniadze ludzie zrobia wszystko, R. Bilski, Urodziłam się z topata, [przedmowa P. Chmielewski], Warszawa 2010, s. 81. Nie sposób przyjąć 
Północnoatlantyckiego podjęło decyzję o zmasowanym natarciu z powietrza na serbskie pozycje wokół Sarajewa. 30 sierpnia 1995 r. o drugiej nad ranem w misji „Deliberate Force" na koszary i baterie artylerii skierowano z rozkazem ich zniszczenia ponad 60 maszyn bojowych (głównie F-16) ${ }^{54}$. Lotnictwo NATO uderzyło nazajutrz jeszcze mocniej, atakując łącznie ponad 90 celów Armii Republiki Serbskiej (VRS), w tym głównie gniazda wyrzutni rakiet i składy amunicji ${ }^{5}$. Dla powstrzymania wojny były to działania słuszne, jakkolwiek słowo prawdy o tym, że bynajmniej nie Serbowie byli sprawcami tragedii, potrzebnej do niewielkiej manipulacji przedzierające się przez „zmowę milczenia”, nie motywuje bynajmniej do takiej postawy oficjalnego Sarajewa.

Niełatwo znaleźć odpowiedź na pytanie, czy długo jeszcze (jeśli w ogóle) czynniki tamtejsze obstawać będą przy negowaniu zweryfikowanych, udokumentowanych „przedsięwzięć”, jak np. dokonanie w maju i czerwcu 1992 r. przez 10. Brygadę Górską Armii Republiki Bośni i Hercegowiny (ARBiH), dowodzona przez Dušana Topalovicia „Caco”, przy wsparciu grupy „egzekucyjnej” niejakiego Ševe, mordu na grupie od 1,5 tys.

za niektórymi badaczami (np. K. Krysieniel, W cieniu Dayton. Bośnia i Hercegowina między etnokracja $i$ demokracja konsocjonalna, Warszawa 2012, s. 178, przypis 161), że fakt wskazania Serbów jako winowajców tragedii w wyroku ICTY z 12 listopada 2009 r. na gen. Dragomira Miloševicia, dowódcę korpusu wojsk Republiki Serbskiej, który oblegał Sarajewo w czasie wojny (29 lat pozbawienia wolności), pozwala niejako, „mimo wszystko”, zadowolić prawdę.

${ }^{54}$ Od zestrzelenia przez myśliwce NATO w lutym 1994 r. czterech maszyn szkolno-bojowych typu Super Galeb, bioracych udział w walkach o Bihać, tzw. zdecydowane kroki międzynarodowe przeciw siłom serbskim były raczej deklarowane niż wdrażane.

${ }^{55}$ Więcej o akcji sił NATO zob. Deliberate Force. A Case Study in Effective Air Campaigning. Final Report of the Air University Balkans Air Campaign Study, ed. by R.C. Owen, Alabama 2000. 
do nawet 3 tys. prawosławnych. Komisja powołana przez miejscowe organizacje serbskie zidentyfikowała około 1 tys. ciał (głównie z wąwozu Kazani) i przekazała listę ofiar do Międzynarodowego Trybunału Sprawiedliwości. Decydenci światowi woleli jednak zło wojny wiązać wyłącznie ze sprawstwem Belgradu, Pale czy Knina - opcja dogadzająca szefostwu Partii Akcji Demokratycznej (SDA) ,prawdziwa” była tym bardziej, że już pierwsze miesiące konfliktu unaoczniły przewagę sił VRS, które dzięki uzbrojeniu i wyposażeniu zajmowały coraz to nowe miasta i obiekty ${ }^{56}$.

Mająca za sobą współczucie opinii międzynarodowej strona muzułmańska, niechętnie zapisywała na swoje konto traumatyczne zbrodnie, jakimi wsławili się mudżahedini podlegający 3. Korpusowi ARBiH z kwatera główną w Zenicy, zwłaszcza zaś 7. Brygada. Żaden z organów władzy ani kierownictw partyjnych na terenie Federacji BiH nigdy nie odniósł się do zarzutów pod adresem A. Izetbegovicia o osobiście wydawane rozkazy ataku przybyłym „na dżihad”, zagrzewanie do rytualnego ścinania głów, odznaczającego potem za gorliwość w „realizacji zadań” najkrwawszych oprawców orderem Złotej Liliii ${ }^{57}$.

Za popełnianie okrucieństw i zbrodni, zwłaszcza na ludności cywilnej, długo potępiano jedynie bośniackich Serbów i Federacyjną (nowa) Republikę Jugosławii, ponieważ dysponowała ona dawna armia, a przy sterze pozostawali komuniści występujący wówczas pod socjalistycznym szyldem. Oceny te sprawiły, że kraj ten 12 maja 1992 r. zawieszono w pracach

${ }^{56}$ Więcej zob.: E. O'Ballance, Civil War in Bosnia 1992-94, LondonNew York 1995; M.-J. Calic, Der Krieg in Bosnien-Herzegovina. Ursachen - Konfliktstrukturen - Internationale Lösungsversuche, Frankfurt am Main 1995.

${ }^{57}$ M. Toholj, „Sveti ratnici” $i$ rat u Bosni $i$ Hercegovini, Beograd 2001, s. 108. 
KBWE, a 30 maja tegoż roku ONZ wprowadziła wobec niego sankcje. Później dopiero społeczność światowa dostrzec miała, iż od postaw skrajnie nacjonalistycznych, wypędzeń, grabieży, zastraszania, organizowania obozów koncentracyjnych, wreszcie morderstw, nie wolna była żadna ze stron ${ }^{58}$.

Kto wie, czy nie większe jeszcze zagrożenia płyną z ukorzenianiem się na Bałkanach (Bośnia, Kosowo, po części Macedonia, enklawy czarnogórskie) radykalnego islamu jako źródła konfliktów społecznych i terrorystycznego zagrożenia dla Europy. Propagowany tu z powodzeniem konserwatywny islam z Arabii Saudyjskiej, wsparty przykładem ${ }^{59}$ oddania za braci w Mahomecie w latach wojny domowej w Bośni (19921995), Kosowie (1996-1999) i Macedonii (2001), hojnością

${ }^{58}$ „Doceniona” dopiero u zarania XXI w. (np. K. Kurspahic, Prime Time Crime. Balkan Media in War and Peace, Washington 2003) rolę w propagowaniu nienawiści „wszystkich do wszystkich” odegrały media, ogromną - centra propagandowe w Belgradzie, Zagrzebiu czy Sarajewie. O ile z pierwszego rozpowszechniano ornamentykę czetnicka, przywoływanie krzywd z lat 1941-1944, na front wysyłano popularnych artystów; drugi specjalizował się w etosie ustaszowskim, kulcie herosów NDH, kompozycjach typu Danke Deutschland, Lilli Marlen czy folkowym straszeniem nowym Jasenovcem przez Marko Perkovicia; w trzecim gloryfikowano organizację Mladi muslimani (założoną w 1941 r.), zbliżoną ideowo do Bractwa Muzułmańskiego, apoteozowano Mehmeda Spaho, Ibrahima Maglajlicia, A. Izetbegovicia, Hasana Čengicia, akcje odwetowe milicji Muhameda Pandžy, ale i „sagę mudżahedińską”, artykułowano Deklarację Muzułmańska z 1970 r., ideały zaczerpnięte z Pakistanu czy Arabii Saudyjskiej, nagłaśniano krzepiące inspekcje Izetbegovicia w obozach dla innowierców (np. w drugiej połowie 1992 r. w Čelebici, gdzie więziono około 900-1100 Serbów, na 200 kobietach dopuszczono się gwałtu, część przetrzymywanych zabito), to cele osiagano w zasadzie identyczne: motywowanie do wojny „aż do ostatecznego zwycięstwa”.

${ }^{59} \mathrm{~W}$ tym tysiącami bestialskich mordów na cywilnej ludności serbskiej, zbiorowymi gwałtami na prawosławnych, ćwiartowaniu ofiar z użyciem pił tarczowych itp. 
różnych fundacji (np. Al-Haramain \& Al Masjed Al-Aqsa Charity, będącej agendą Ar-Rabita al-Alam al-Islami, powiazanej z Al-Kaida, Al-Furkan czy Taliba International) ${ }^{60}$. Obok wychodzącego z „charytatywnych” organizacji, finansujacych i wcześniej bojowników z Libii, Syrii, Jordanii i innych państw, wprowadzania do obiegu dziesiątek milionów dolarów z działalności przestępczej, zamachów na budynki rządowe i „niewiernych” (m.in. zastrzelenie przez Mohameta Meraha w Tuzli w marcu 2012 r. siedmiu osób; zabicie przez Arida Ukę, „pozyskanego” Kosowianina, w 2011 r. we Frankfurcie nad Menem dwóch amerykańskich żołnierzy) - coraz niebezpieczniejsze stają się różne „bataliony śmierci”, szkolone do walki z przeciwnikami szariatu, rekrutujace tzw. białych mudżahediów ${ }^{61}$ celem przerzucenia do Europy Zachodniej i USA. Grupy „nowych” radykałów objawiają się na coraz to innych terenach, przejmuja meczety, rozpalają nienawiści religijne. Za środki szerokim strumieniem napływajace z Półwyspu Arabskiego - od rządów, organizacji, fanatycznych donatorów - zakładane są centra szkoleniowe, wykorzystujące sprzyjające ideologii bezrobocie, ubóstwo, brak wiary w lepszą przyszłość.

W gruncie rzeczy nie tylko ład podyktowany w bazie lotniczej Dayton (w stanie Ohio), ale żadne porozumienie, kończące kolejne konflikty na Bałkanach na przełomie XX i XXI w., nie rozwiązało problemów etnicznych, nie usunęło resentymentów i podziałów. Większość z nich pogłębiła natomiast przepaść między wyznawcami islamu i chrześcijanami ${ }^{62}$

${ }^{60}$ Więcej zob. J. Elsässer, Jak dżihad przybyt do Europy. Wojownicy Boga i tajne stużby na Batkanach, przeł. M. Bochwic-Ivanovska, Warszawa 2007.

${ }^{61}$ Wywodzących się m.in. z doborowej formacji Abu Bakra as-Sadika.

${ }^{62} \mathrm{~K}$. Izak, Radykalny islam na Batkanach źródtem konfliktów społecznych $i$ terrorystycznego zagrożenia dla Europy, „Przegląd Bezpieczeństwa Wewnętrznego" 2013, nr 9 (5), s. 72. 
(wykopanymi w końcówce stulecia rowami katolicko-prawosławnych niechęci). Transmisja wpływów wahabickich, agresywnych wspólnot albańskich, unaoczniła się w Macedonii, odnotowując tu edukacyjny i propagandowy (co gorsza: militarny i polityczny) sukces, zadomowiła w Sandżaku, zdaje się coraz gruntowniej kotwiczyć w Bułgarii ${ }^{63}$.

Doktryna, wsparta sponsoringiem naftowych potęg, rozbiła dominujacca do niedawna na Bałkanach, najmniej ortodoksyjną - hanaficką szkołę islamu. Pokonała też kilkuwiekową tradycję sasiedztwa wyznawców islamu i chrześcijaństwa. Trudno nie podzielać opinii analityków wyrażających opinie, że radykalny islam zagraża stabilizacji $\mathrm{w}$ tym regionie. Poza zagrożeniem terrorystycznym, łatwym do przekserowania do środkowej i zachodniej części kontynentu, napastliwość fundamentalistyczna dotyka społeczności miejscowych: kultura przemocy i nieuznawanie porządku prawnego zamieszkiwanych krajów, nienawiść do innych stanowią łącznie o wysokim prawdopodobieństwie eskalacji niebezpieczeństw.

Nie sposób oprzeć się refleksji, że tak jak przewartościowania na arenie międzynarodowej, jakie pojawiły się pod koniec lat 80. XX w., szczególnie procesy rozpadu Związku Radzieckiego, spowodowały pojawienie się zjawisk nie mieszczących się w standardowych definicjach zagrożenia, tak niełatwo jest identyfikować jego potencjalne zarzewia, podmioty, organizacje w przestrzeni bałkańskiej. Przydając baczna uwagę konstatacjom badaczy, iż bezpieczeństwo militarne,

${ }^{63}$ Proces reislamizacji państwa wydaje się tu szczególnie konfliktogenny, zważywszy, że dla wielu islam, kojarzący się z religią ciemiężców, jest trudny do zaakceptowania. Nie wykluczone jednak, że „ostoje” nowej konfesji, jak wzniesiony w Dawidkowie pomnik-mauzoleum Enihana Baby, świętego muzułmańskiego męża, który podbił Rodopy, mordując 100 tys. Bułgarów, są znakiem przewartościowań. 
częstokroć komparowane z ekonomicznym, jest filarem bezpieczeństwa ekonomicznego ${ }^{64}$, można w realiach omawianego regionu także i odwrócić wektory, tj. wskazać na skutkowanie słabo akceptowalnego przez zbiorowość zgasłej federacji ładu politycznego, a także zapaści gospodarczej - konfliktem zbrojnym.

Analiza biegu spraw, jakie miały miejsce po ogłoszeniu secesji Słowenii i Chorwacji, a w ślad za nimi decyzjami o ogłoszeniu bytów oddzielnych przez Bośnię i Hercegowinę, Macedonię, Czarnogórę, na końcu wspartą przez Zachód pavarsije kosowska - zdaje się mało „kompatybilna” z siatkami pojęciowymi (mimo że niejednokrotnie rozmytymi i nieostrymi) w obszarze bezpieczeństwa. Badacze, wiodący namiętne spory o kwestie metodologiczne, kwalifikację zagrożeń, paradygmaty, o sprawy dla teorii tak ważące, czy odrębność młodej dyscypliny nauk o bezpieczeństwie nie jest nadużyciem - niechętnie zejść chca na poziom bałkańskiej specyfiki, tamtejszej, trudnej z europejskich i zamorskich centrów do ogarnięcia rzeczywistości.

Logika zdarzeń w zachodniej części, chociaż nie tylko, Półwyspu Bałkańskiego, gdzie wszystkim państwom sukcesyjnym wieszczono z „centrów mocy” (pod warunkiem przyjęcia zobowiązań demokratycznych i respektowania zasad prawa międzynarodowego), rychłe wprowadzenie do struktur integracji euroatlantyckiej, niekoniecznie musi być przewidywalna. Przyszłość, pewnie bardzo nieodległa, dowieść może wzmożenia tendencji separatystycznych Sandżaku, czy nieznośność bytu dyskryminowanego korpusu prawosławnego w Kosowie (domagania się jego podziału na zasadach etnicznych). Kto wie, czy marginalizowanie roli Belgradu

${ }^{64}$ Zob. M. Malec, Percepcja bezpieczeństwa: definicje wymiary, paradygmaty, Warszawa 2006, s. 41. 
w procesie stabilizacyjnym nie przełoży się na zradykalizowanie postaw Węrów z Wojwodiny ${ }^{65}$. Diagnozy dotyczace kwestii tak zasadniczych, jak to, czy Macedonia oprze się próbom zdominowania przez żywioł albański, a mieszkańcy Republiki Serbskiej zechca podtrzymywać formalną już tylko więź z Federacją Bośni i Hercegowiny; czy, alternatywnie, nie nastapi tu recydywa dążenia do połączenia z „macierzą" - obciążone są znaczacym ryzykiem pomyłki. Nie mniejszej niż to, czy „demograficzny nacjonalizm”66, który zdał egzamin w byłej prowincji kosowskiej ${ }^{67}$, nie odniesie kolejnego sukcesu w Czarnogórze, a zatomizowane kantony „daytońskie”, o przemożnym wpływie fundamentalizmu, nie staną się groźnymi dla Europy przyczółkami działań grup zorganizowanych Państwa Islamskiego. Czy w tym stanie rzeczy społeczność Zachodu, wliczając do niej aspirującą środkowo-wschodnią część Starego Kontynentu, stać na potencjalne konsekwencje umocnienia się

${ }^{65}$ M. Samardžić, Tranzicija i manjine u Vojvodini, Zrenjanin 2002; Predlog statuta autonomie Pokrajine Vojvodine, Novi Sad [oktobar] 2008. Społeczno-polityczną aurę Wojwodiny kreśli A. Jagiełło-Szostak, Idea narodu politycznego kontra etnonacjonalizmy. Od jugoslawizmu do jugonostalgii, Wrocław 2013, s. 255-260.

${ }^{66}$ Kwestię tę przybliża m.in. A. Malinowski, Polityczne dzieje Kosowa (1974-2008), Toruń 2014.

${ }^{67} \mathrm{~W}$ literaturze polskiej, poza „poprawnymi politycznie”, nietrudno odnaleźć obiektywne relacje z kosowskiej „drogi do wolności”, jak np. w pracy Krzysztofa Kubiaka: Na poczatku kwietnia 2004 r. w Kosowie miaty miejsce masowe $i$ centralnie zorganizowane wystapienia przeciw mniejszości serbskiej. [...] Przez kilka dni Serbowie byli obiektem napaści i linczów ze strony Albańczyków. Ttumy uzbrojone w noże, karabiny i granaty zaatakowaty Serbów, najpierw w dwuetnicznej Mitrovicy, a potem w kilkunastu innych miasteczkach prowincji. Zginęło 28 osób, a około 600 zostało rannych. Albańczycy spalili 25 prawostawnych serbskich cerkwi i ponad 100 serbskich domów. Co najmniej 3 tys. serbskich uciekinierów znalazło schronienie w budynkach ONZ $i$ pod osłona żotnierzy KFOR, K. Kubiak, Wojny, konflikty zbrojne i punkty zapalne na świecie. Informator 2007, Warszawa 2007, s. 64. 
wpływów Rosji w tym obszarze, swoisty klin, o długiej, wszak carskiej jeszcze, strategicznej tradycji ekspansywnej?

Wątpliwości powyższe nie wyczerpują indeksu pytań, jakie winny nurtować analityka. Nie przybliżają nawet do wyznaczenia priorytetów badawczych, jeśli pretenduje się do grona znawców regionu. Sygnalizują ewentualne zarzewia niepokojów, potencjalnych konfliktów w regionie, który ma „przywilej” zapisywania się w dziejach jako detonator zdarzeń, jeśli nie zawsze o charakterze globalnym, to zdecydowanie przekraczającym przestrzeń wyznaczana geografią fizyczna. Tym większe należy się uznanie śp. Profesorowi Pawłowi Chmielewskiemu za zainaugurowanie dyskursu na temat zachodniobałkańskiego wymiaru bezpieczeństwa i jego projekcji na obniżenie/zawyżenie poziomu zagrożeń o charakterze powszechnym. Tym większe też wyzwania wyznaczają kierunki dociekań i zadania podejmowane przez Centrum Naukowo-Badawcze Uniwersytetu Łódzkiego „Bałkany na przełomie XX/XXI w.”, którego przedwcześnie zmarły Profesor był inicjatorem i założycielem. 